\title{
PHEOCHROMOCYTOMA TREATED BY LAPAROSCOPIC SURGERY
}

Lísias Nogueira Castilho, Paulo José de Medeiros, Anuar Ibrahim Mitre, Francisco Tibor Dénes, Antonio Marmo Lucon and Sami Arap

RHCFAP/3010

CASTILHO L N et al. - Pheochromocytoma treated by laparoscopic surgery. Rev. Hosp. Clín. Fac. Med. S. Paulo 55 (3):93-100, 2000 .

SUMMARY: Objective: To evaluate the results of the laparoscopic technique in the treatment of adrenal pheochromocytoma.

Method: Ten patients, 7 men and 3 women, between 10 and 67 years of age (mean 48) with pheochromocytoma underwent transperitoneal laparoscopic adrenalectomy and were evaluated retrospectively, based on clinical, laboratory, and pathological diagnosis. In all cases there was a solid unilateral adrenal tumor, 5 on the left side and 5 on the right side, whose greater diameter varied from 7 to $80 \mathrm{~mm}$ (mean 32). Nine of the 10 patients were chronically hypertensive or had already had hypertensive crises. One patient was normotensive, but presented metabolic alterations suggestive of adrenergic hyperfunction.

Results: No deaths occurred in this series. There were two (20\%) conversions to open surgery, one due to venous bleeding and one due to the difficulty of dissection behind the vena cava in a patient presenting a partially retro-caval tumor. Surgical time in the 8 non-converted cases ranged from 70 to 215 minutes (mean 136). One patient (10\%) received blood transfusion, and another (10\%) presented two complications - acute renal failure and a subcutaneous infection. Both had been converted to open surgery. None of the non-converted cases was transfused or presented complications. Hospital discharge occurred between the $2^{\text {nd }}$ and $11^{\text {th }}$ postoperative day (mean 3). The pathological exam of the surgical specimens confirmed the diagnoses of pheochromocytoma in all 10 cases, one of them associated with an aldosterone-producing cortical tumor.

Conclusions: Laparoscopic adrenalectomy for selected patients presenting pheochromocytoma is feasible and provides good results.

DESCRIPTORS: Pheochromocytoma. Adrenal tumor. Laparoscopic adrenalectomy.

Laparoscopic adrenalectomy was originally described by Canadian and Japanese authors, in $1992^{1,2}$. Since then, according to the Index Medicus, approximately 300 studies on this subject have been published, totaling more than 1000 performed adrenalectomies, which reflects not only significant international experience, but also a growing interest by urologists and surgeons who operate on endocrine glands. Laparoscopic adrenalectomy has been considered for some time to be the gold standard treatment for benign adrenal tumors of small volume, functioning or not ${ }^{3}$, due to the better results obtained when compared to those of open surgery, in all aspects - morbidity, hospitalization, convalescence, bleeding, pain, etc., including costs ${ }^{4-15}$. Concerning operative time in laparoscopic surgeries, although it was initially longer than for open surgery, bringing doubts and criticisms, currently, it is approximately the same since the learning curve has been climbed $^{16}$.

The treatment of pheochromocy-

From the Division of Urology, Hospital das Clínicas, Faculty of Medicine, University of São Paulo. toma by laparoscopy has been the subject of studies and controversies since 1992, when it was first successfully performed $^{1}$. Laparoscopic technique presents several demonstrated advantages over open surgery, both in unilateral and bilateral pheochromocytoma ${ }^{17-27}$.

We present below our experience with laparoscopic treatment of pheochromocytoma.

\section{METHOD}

Patients were selected for unilateral or bilateral laparoscopic adrenalec- 
tomy, with different diagnoses, between May 1994 and December 1999. Sent from private clinics and from the Division of Urology of the Hospital das Clínicas da FMUSP, all patients were initially evaluated by endocrinologists and sent to us only after surgical indication was firmly established. Exclusion criteria for laparoscopic surgery were: clinical-radiological suspicion of primary malignancy of the adrenal gland (of difficult characterization), moderate or severe respiratory insufficiency, moderate or severe cardiac or coronary insufficiency, uncorrected coagulopathy, intraperitoneal or abdominal wall infections, and refusal of the patient or endocrinologist to accept laparoscopic surgery. Previous abdominal surgery, obesity, and abdominal wall hernias were not criteria for exclusion. Sixty-one patients fulfilled our pre-requisites and underwent laparoscopic procedures.

After rigorous clinical, laboratory, and radiologic investigations performed by endocrinologists, the $61 \mathrm{pa}-$ tients were selected for laparoscopic surgery with the following pre-operative diagnoses (Table 1): non-functioning tumor (22), Cushing's syndrome or disease (16), hyperaldosteronism (10), pheochromocytoma (10) and virilizing tumor (3). All patients underwent echography (US) and computerized tomography (CT) of the abdomen. Some additionally underwent magnetic nuclear resonance (MRI) procedures for better characterization of small nodules. All patients with evidence from these tests of pheochromocytoma, also underwent radioisotopic exam with MIBG (meta-iodine-benzylguanidine). Patients presenting nonfunctioning tumors and previous history of cancer were also investigated with bone scan and chest radiograms.

We retrospectively analyzed all cases with an initial diagnosis of pheochromocytoma, comparing them with the cases that had a diagnosis of pheo- chromocytoma confirmed (Table 2).

Of the 10 pheochromocytoma cases confirmed by pathologic examination, 7 were from male and 3 from female patients. The majority $(90 \%)$ were of white color. Age varied from 10 to 67 years (mean 48). All patients presented the disease unilaterally, with a normal contralateral gland. Three cases presented family history of pheochromocytoma.

Pre-operative clinical preparation of the patients consisted basically of rest, low sodium diet, and administration of the alpha-blocking agent prasozine, in doses of 4 to $20 \mathrm{mg}$ per day during the weeks prior to surgery. Surgical preparation conformed to the following general norm, adapted for each case: light diet two days before surgery, and a liquid diet and enema, with $500 \mathrm{ml}$, to empty the rectum, in the night preceding the procedure; abdominal trichotomy immediately before surgery; and prophylactic administration of wide spectrum antibiotic during the induction of anesthesia.

Under general anesthesia, the patients were positioned on the surgical table in $45^{\circ}$ lateral decubitus. Pads, adhesive tapes and, in some cases, elastic socks, were adequately placed to avoid ischemic injuries, burns, nervous lesions, and venous thrombosis.

Standard procedures were executed and the following technical steps were followed:

Table 1 - Distribution of 61 patients treated in accordance to the clinical-laboratorial indication of laparoscopic surgery.

\begin{tabular}{lll}
\hline Surgical indication & patients (n) & $\%$ \\
\hline Nonfunctioning tumor & 22 & 36 \\
Cushing & 16 & 26.2 \\
Hyperaldosteronism & 10 & 16.4 \\
Pheochromocytoma & 10 & 16.4 \\
Virilization & 3 & 4.9 \\
\hline Total & 61 & 100 \\
\hline
\end{tabular}

$\left.1^{\text {st }}\right) \mathrm{CO}_{2}$ insufflation of the peritoneal cavity through the introduction of the Veress needle in the abdomen, either on the midline, on the lower border of the umbilicus, or on the midclavicular line on the same side the adrenalectomy would be performed. In all cases the transperitoneal approach was employed.

$\left.2^{\text {nd }}\right)$ Once the pneumoperitoneum was obtained, four $11 \mathrm{~mm}$ trocars were inserted in the abdomen according to the pattern in figure 1 . In the only child in the group, and in very thin patients, two $11 \mathrm{~mm}$ and two $5 \mathrm{~mm}$ trocars were used.

$3^{\text {rd }}$ ) Once the cavity was inspected, the equipment and the patient's position were adjusted and we proceeded to the medial mobilization of the colon, and exposure of the renal fascia and the great vessels-renal vein on the left and vena cava on the right.

$\left.4^{\text {th }}\right)$ The central adrenal vein, tributary of the vena cava on the right side and of the renal vein on the left, was then identified and sectioned between metallic clips before manipulation of the gland to avoid hemodynamic disturbances due to adrenergic discharges.

$\left.5^{\text {th }}\right)$ Once the central vein, almost always the sole one, was cut, the gland was freed of neighboring structures with care, in order to avoid visceral or vascular lesions. Small arterial, lymphatic or venous vessels were simply cauterized.

$\left.6^{\text {th }}\right)$ Once completely freed, the surgical specimen was removed from the abdomen inside a special plastic bag, by means of an enlargement of one of the incisions in the abdominal wall, usually the most inferior one, close to the iliac spine.

$\left.7^{\text {th }}\right)$ Once the specimen was removed, we proceeded to the revision of the cavity and suturing of the surgical wounds in two layers.

All surgical specimens were sent to pathologic examination. Those that raised doubts about their diagnoses 
Table 2 - Tabulation of all the cases with clinical-laboratorial suspition of pheochromocytoma and of those with pathological confirmation.

\begin{tabular}{|c|c|c|c|c|c|c|c|c|c|c|c|c|}
\hline Case & Gender & Age * & Race & $\mathrm{BMI}^{* *}$ & $\begin{array}{c}\text { Clinical } \\
\text { presentation }\end{array}$ & $\begin{array}{c}\text { Duração dos } \\
\text { sintomas }\end{array}$ & $\begin{array}{l}\text { Pre-op. } \\
\text { diagnosis }\end{array}$ & Side & $\begin{array}{c}\text { Greater } \\
\text { axis }(\mathrm{mm})\end{array}$ & Surgery & Pathology & Final diagnosis \\
\hline 1 & $\mathrm{M}$ & 52 & $\mathrm{~W}$ & 26.4 & $\begin{array}{c}\text { Severe } \\
\text { hypertension }\end{array}$ & 2 anos & $\begin{array}{c}\text { Familiar } \\
\text { pheochro- } \\
\text { mocytoma }\end{array}$ & $\mathrm{L}$ & 55 & Jun/94 & $\begin{array}{l}\text { Pheochro- } \\
\text { mocytoma } \\
\end{array}$ & $\begin{array}{l}\text { Pheochro- } \\
\text { mocytoma }\end{array}$ \\
\hline 2 & $\mathrm{~F}$ & 55 & $\mathrm{~W}$ & 27.2 & $\begin{array}{c}1 \text { single } \\
\text { hypertensive } \\
\text { crisis } \\
\end{array}$ & 3 anos & $\begin{array}{l}\text { Familiar } \\
\text { pheochro- } \\
\text { mocytoma }\end{array}$ & $\mathrm{L}$ & 28 & May/1996 & $\begin{array}{l}\text { Pheochro- } \\
\text { mocytoma }\end{array}$ & $\begin{array}{l}\text { Pheochro- } \\
\text { mocytoma }\end{array}$ \\
\hline 3 & M & 10 & $\mathrm{~W}$ & 21.5 & $\begin{array}{c}\text { Hypertensive } \\
\text { crisis }\end{array}$ & 1 ano & $\begin{array}{l}\text { Pheochro- } \\
\text { mocytoma }\end{array}$ & $\mathrm{R}$ & 40 & Jun/96 & $\begin{array}{l}\text { Pheochro- } \\
\text { mocytoma }\end{array}$ & $\begin{array}{l}\text { Pheochro- } \\
\text { mocytoma }\end{array}$ \\
\hline 4 & M & 38 & $\mathrm{~W}$ & 28.3 & $\begin{array}{l}\text { Hypertensive } \\
\text { crisis }\end{array}$ & 8 meses & $\begin{array}{l}\text { Familiar } \\
\text { pheochro- } \\
\text { mocytoma }\end{array}$ & $\mathrm{R}$ & 15 & Oct/1996 & $\begin{array}{l}\text { Pheochro- } \\
\text { mocytoma }\end{array}$ & $\begin{array}{l}\text { Pheochro- } \\
\text { mocytoma }\end{array}$ \\
\hline 5 & $\mathrm{~F}$ & 43 & B & 33.5 & $\begin{array}{c}\text { Severe } \\
\text { hypertension }\end{array}$ & 8 anos & $\begin{array}{l}\text { Pheochro- } \\
\text { mocytoma }\end{array}$ & $\mathrm{L}$ & 15 & Aug/1998 & $\begin{array}{l}\text { Pheochro- } \\
\text { mocytoma }\end{array}$ & $\begin{array}{l}\text { Pheochro- } \\
\text { mocytoma }\end{array}$ \\
\hline 6 & M & 46 & $\mathrm{~W}$ & 26.4 & $\begin{array}{l}\text { Hypertensive } \\
\text { crisis }\end{array}$ & 5 anos & $\begin{array}{l}\text { Pheochro- } \\
\text { mocytoma }\end{array}$ & $\mathrm{R}$ & 80 & Sep/1998 & $\begin{array}{l}\text { Pheochro- } \\
\text { mocytoma }\end{array}$ & $\begin{array}{l}\text { Pheochro- } \\
\text { mocytoma }\end{array}$ \\
\hline 7 & M & 57 & $\mathrm{~W}$ & 20.4 & $\begin{array}{c}\text { Hypertension } \\
\text { and hypocalemia }\end{array}$ & 9 meses & $\begin{array}{l}\text { Hyperaldos- } \\
\text { teronism }\end{array}$ & $\mathrm{L}$ & 10 & Jan/99 & $\begin{array}{l}\text { Cortical adenoma } \\
\text { and pheochr- } \\
\text { mocytoma }\end{array}$ & $\begin{array}{c}\text { Pheochro- } \\
\text { mocytoma and } \\
\text { hyperaldosteronism }\end{array}$ \\
\hline 8 & $\mathrm{~F}$ & 65 & $\mathrm{~W}$ & 23.8 & Assymptomatic & sem sintomas & $\begin{array}{c}\text { Pheo? } \\
\text { Nonfunctioning? }\end{array}$ & $\mathrm{L}$ & 41 & Feb/1999 & $\begin{array}{l}\text { Pheochro- } \\
\text { mocytoma }\end{array}$ & $\begin{array}{l}\text { Pheochro- } \\
\text { mocytoma }\end{array}$ \\
\hline 9 & M & 67 & W & 23.2 & $\begin{array}{c}\text { 1single } \\
\text { hypertensive } \\
\text { crisis }\end{array}$ & 6 meses & $\begin{array}{c}\text { Pheo? } \\
\text { Nonfunctioning? }\end{array}$ & $\mathrm{R}$ & 35 & Mar/99 & $\begin{array}{l}\text { Pheochro- } \\
\text { mocytoma }\end{array}$ & $\begin{array}{l}\text { Pheochro- } \\
\text { mocytoma }\end{array}$ \\
\hline 10 & M & 47 & $\mathrm{~W}$ & 27.8 & $\begin{array}{c}\text { Hypertensive } \\
\text { crisis }\end{array}$ & 7 anos & $\begin{array}{l}\text { Pheochro- } \\
\text { mocytoma }\end{array}$ & $\mathrm{R}$ & 60 & Apr/1999 & $\begin{array}{l}\text { Pheochro- } \\
\text { mocytoma }\end{array}$ & $\begin{array}{l}\text { Pheochro- } \\
\text { mocytoma }\end{array}$ \\
\hline 11 & $\mathrm{~F}$ & 54 & $\mathrm{~W}$ & 26.5 & $\begin{array}{c}\text { Moderate } \\
\text { hypertension }\end{array}$ & 5 anos & $\begin{array}{c}\text { Pheo? } \\
\text { Nonfunctioning? }\end{array}$ & $\mathrm{L}$ & 30 & Nov/99 & Cortical adenoma & $\begin{array}{l}\text { Nonfunctioning } \\
\text { tumor }\end{array}$ \\
\hline
\end{tabular}

*Years; **Body Mass Index.

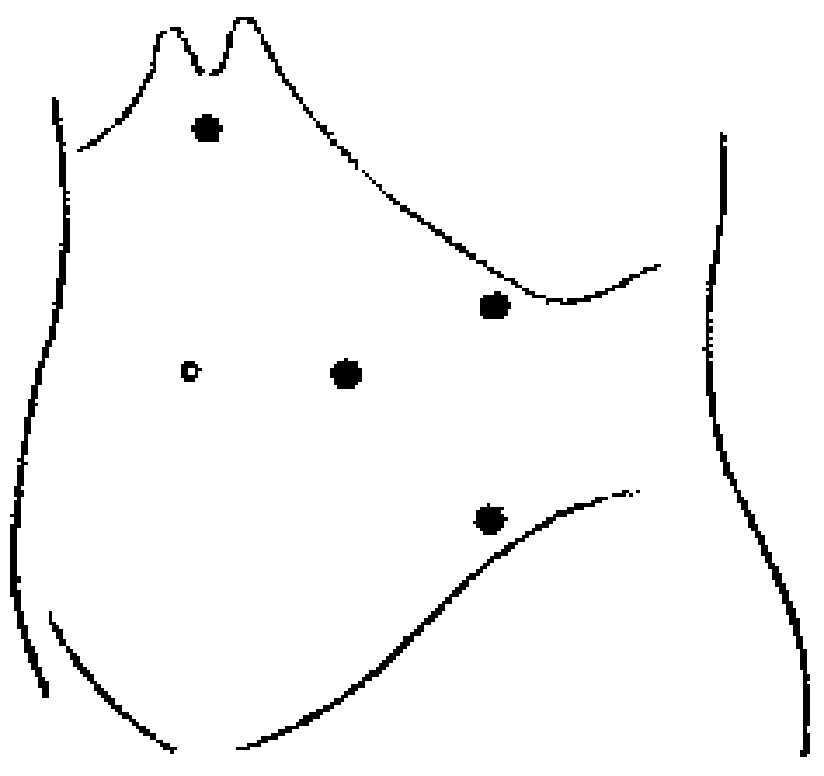

\section{th mint}

Figure 1 - Habitual position of the four $11 \mathrm{~mm}$ trocars to perform a left adrenalectomy. 
were submitted to immunohistochemical exam.

\section{RESULTS}

No deaths occurred in this series, either during the hospitalization period or during the follow-up period, which ranged from 1 to 62 months (mean 22). Case 7 did not have a clinical or laboratory diagnosis of pheochromocytoma, but of hyperaldosteronism, despite presenting severe hypertension. The pathologic examination with immune-histochemistry confirmed the co-existence of pheochromocytoma. Case 11 had a doubtful diagnosis because some tests, such as the MIBG and serum dosages of catecholamines were abnormal, but borderline; the pathologic examination showed a cortical adenoma, probably non-functioning and unrelated to the moderate arterial hypertension presented by the patient, which remained unaltered in the post-operative period. Therefore, we considered the results of the 10 patients that had the final diagnosis of pheochromocytoma, excluding case 11 (Table 3 ).

In two cases (3 and 10), there was need for conversion to open surgery (20\%), the first one due to a lesion of the adrenal vein, and the other due to difficulty in finding a dissection plane between the tumor, measuring $6 \mathrm{~cm}$, and the vena cava (Table 3 ).

Surgical time varied from 70 to 315 minutes. Excluding the two cases that were converted, average surgical time was $136 \mathrm{~min}$. (range, $70 \mathrm{~min}$. to 215 min.).

There were intra-operative occurrences in two cases. In case 3 , a secondary adrenal vein that drained to the liver was accidentally severed, and we were unable to attain hemostasia. This was the only case that required blood transfusion, and it was converted to open surgery. In case 9, a small lesion of the vena cava was sutured without difficulty, and the laparoscopic procedure was completed.

There were two complications on the same patient (case 10): acute renal failure, treated with diuretics and dopamine, with no need for dialysis, and subcutaneous infection after hospital discharge, drained spontaneously. In this patient laparoscopic surgery had been converted to open surgery.

Only case 7 remained hypertensive in the late post-operative period, although under easy control. This patient had undergone two kidney transplants, had a chronic nephropathy, and had been hypertensive for over 20 years. All others became normotensive without medication. All 10 patients underwent image exams with MIBG, US and
CT, in addition to metabolic exams. In none were alterations compatible with pheochromocytoma found during the follow-up period.

All patients were fed and walked in the first post-operative day. Hospital discharge occurred between the $2^{\text {nd }}$ and $11^{\text {th }}$ post-operative day $($ mean $=3$ days).

Pathologic examination of the 10 specimens demonstrated the presence of a single solid tumor in all of them: the smallest specimen, a gland with a $7 \mathrm{~mm}$ diameter nodule, weighed $5 \mathrm{~g}$; the largest, a tumor with a $80 \mathrm{~mm}$ diameter, weighed $250 \mathrm{~g}$. Only the adrenal gland of case 7 presented a different result: a cortical nodule (associated to the hyperaldosteronism) and medullar hyperplasia. The diagnosis of pheochromocytoma in the hyperplastic zone was established only through immunohistochemical exams.

\section{DISCUSSION}

Surgical removal of the adrenal gland by laparoscopy began in 1992 and has since been performed by dozens of groups on hundreds of patients. Pheochromocytoma has also been approached laparoscopically since $1992^{1}$, but there were doubts concerning the safety of the procedure in light of al-

Table 3 - Results.

\begin{tabular}{|c|c|c|c|c|c|c|c|}
\hline Case & Operative time $(\mathrm{min})$ & Conversion & IO complication & PO complication & Blood transfusion & Hospital discharge & Late evolution \\
\hline 1 & 150 & No & No & No & No & 7 & Normotensive \\
\hline 2 & 135 & No & No & No & No & 8 & Normotensive \\
\hline 3 & 315 & Yes & Venous lesion & No & Yes 5 units & 11 & Normotensive \\
\hline 4 & 140 & No & No & No & No & 3 & Normotensive \\
\hline 5 & 80 & No & No & No & No & 3 & Normotensive \\
\hline 6 & 150 & No & No & No & No & 3 & Normotensive \\
\hline 7 & 70 & No & No & No & No & 3 & Light hypertension \\
\hline 8 & 150 & No & No & No & No & 2 & Normotensive \\
\hline 9 & 215 & No & Caval lesion & No & No & 2 & Normotensive \\
\hline 10 & 250 & Yes & No & $\begin{array}{c}\text { Yes - subc. } \\
\text { infecction and ATN }\end{array}$ & No & 5 & Normotensive \\
\hline
\end{tabular}


terations observed during the $\mathrm{CO}_{2}$ insufflation $^{28}$. However, with increasing experience, it has been verified that the metabolic and hemodynamic alterations observed are of small importance and do not augment the risk in laparoscopic surgery ${ }^{20,27,29,30,31}$. On the contrary, the laparoscopic approach revealed itself superior to open surgery for tumors of up to $6 \mathrm{~cm}$ at the largest diameter, being specially indicated in cases of greater risk, such as bilateral tumors ${ }^{20,25,26}$, tumors in pregnancy ${ }^{20,23}$, multiple tumors ${ }^{20}$ and patients with congestive heart disease ${ }^{32}$. Actually, neither the laparoscopic or the open approach are risk factors themselves, if adequately employed, meaning avoiding the main risk factors of the procedure by controlling the adrenal vein at the beginning, and doing minimal manipulation of the tumor. The risks are inherent to the disease itself, especially when blood pressure levels are very high, and also to the clinical and anesthetic precautions and procedures involved. Pre-operative preparation with alpha-blockers, in our preference prasozine, immediate pre-operative hyperhydration and rigorous hemodynamic control in the surgery room are the main factors determining the success of the procedure. The patient diagnosed with precision, clinically prepared with alpha-blockers, well anesthetized and operated on with the correct technique, open or laparoscopic, rarely presents serious complications. The advantages observed by us and several other authors, concerning the laparoscopic approach over the open approach, are, essentially: shorter hospital stay, pain practically absent, lower morbidity, shorter convalescence time, and better aesthetic results ${ }^{8,33-35}$.

The choice we made for a transperitoneal approach, instead of the extraperitoneal approach others use ${ }^{36,37}$, is due to two facts: first, our greater familiarity with the transperitoneal approach; second, the greater ease of ob- taining control over the adrenal vein in the beginning of the procedure, a task that is more troublesome in the extraperitoneal approach ${ }^{33}$. However, the extraperitoneal approach has been used with increasing frequency and success, particularly for small tumors ${ }^{38}$. The choice of the approach depends on the personal experience of the surgeon and on the dimensions of the tumor. For larger tumors, the transperitoneal approach should be chosen ${ }^{7,8}$. For smaller tumors, apparently both the transperitoneal and the extraperitoneal approaches are equivalent.

The surgical time we recorded, 136 minutes on average, similar to that of other authors using the same technique $^{7,19,20,24}$, and in the experience of our team, is approximately the same as in open surgery. Although others have observed a significantly greater surgical time in laparoscopic surgery ${ }^{17,33}$, we believe that with increasing experience, times tend to even out, as happened in our personal experience with nephrectomy, nephroureterectomy and radical nephrectomy (unpublished data). Even those authors who have found a significant difference in surgical times between laparoscopic and open procedures, consider, as a whole, the results obtained through laparoscopic surgery to be much superior to those of open surgery ${ }^{17}$.

The conversion-to-open-surgery ratio that we had in pheochromocytoma, $20 \%$, is far above our ratio in the whole group of 61 patients we treated, $8 \%$, and this difference probably reflects the small number of pheochromocytoma cases in our series. However, in retrospect, at least one of our two converted cases (Case 3) could have been treated laparoscopically, if we had larger experience, since we sutured a lesion of the vena cava during laparoscopy in a more recent case without great difficulty. Actually, with more experience, the number of conversions to open surgery approaches zero in surgery for pheochromocytoma ${ }^{20}$.

One of our patients (10\%) presented two complications, one of small repercussion, a subcutaneous infection, but another more important, acute renal failure. Reviewing the case, which required conversion due to the retrocaval position of the tumor, greatly increasing the difficulty of the operation, we observed that immediate pre-operative hyperhydration, which we routinely used, was not correctly followed. This omission must have contributed to the hypotension that occurred immediately after the ligation of the adrenal vein while still in the operating room. Patients with pheochromocytoma usually present hypervolemia. Once the intense adrenergic activity is suppressed during the operation, the tendency of these patients is to present pre-renal renal insufficiency, hence the importance of expanding the intravascular bed with saline and colloids hours before the intervention. Authors very experienced with the laparoscopic treatment of pheochromocytoma have obtained complication ratios of $8 \%$ to $16 \%{ }^{20,33}$.

It is relevant that the only patient who underwent blood transfusion and the only one who presented complications were converted. Out of the 8 nonconverted cases, none presented complications or needed blood transfusions.

Although we have operated on 3 cases of familiar pheochromocytoma, a condition considered ideal for the execution of partial adrenalectomy ${ }^{20,38,39}$, we preferred a total adrenalectomy and follow-up of the cases. In case of recurrence in the remaining gland, we intend to perform a partial resection of the gland, a technically simple procedure, especially for tumors of small volume.

The diagnosis of pheochromocytoma cannot always be established before surgical treatment with absolute 
confidence, either because of normal or borderline exams, in cases of functioning pheochromocytomas, or in nonfunctioning tumors. In our series, out of 3 doubtful cases, the diagnosis was not confirmed in one. On the other hand, pheochromocytoma is eventually a pathological finding, especially in the non-functioning cases. We did not have any cases on which the pheochromocytoma was completely nonfunctioning. In case 8 there were no symptoms, but urinary vanilmandelic acid was slightly above normal. Despite this being the only biochemical alteration found, the patient was prepared for the procedure as having a functioning pheochromocytoma, and pathologic examination confirmed the diagnosis. In case 7, diagnosis of hyperaldosteronism was well established, and a pheochromocytoma was found in the immunohistochemical exam; however, the pre-operative biochemical exams were only slightly altered, not leading to the presumptive diagnosis of pheochromocytoma associated with the cortical tumor causing hyperaldosteronism, a rare situation that we never before ob- served. This patient was the only one who remained hypertensive in the late post-operative period (10\%), what is in accordance with the information from the literature about pheochromocytoma, in which about $90 \%$ of treated patients become normotensive immediately or after a few weeks ${ }^{40}$. However, due to the relevant nephrologic history of the patient, it is possible that other factors have contributed to his hypertension.

The largest tumor diameter measured by CT or MRI was $80 \mathrm{~mm}$, but the average of the 10 cases was 32 $\mathrm{mm}$. Pheochromocytomas of large volume are uncommon. Most are less than $6 \mathrm{~cm}$ in their greatest diameter, which emphasizes even more the preference for laparoscopic surgery. However, in tumors of greater volume, the determinant factor for the indication of laparoscopic surgery is the experience of the surgeon, and not an absolute anatomical aspect. Therefore, some authors have successfully removed, by laparoscopy, tumors of 10 , 12 and even $15 \mathrm{~cm}$ in diameter ${ }^{7,8}$. Our experience suggests that tumors of up to $10 \mathrm{~cm}$ on the left side can be successfully approached by laparoscopy, but on the right side, due to the proximity of the vena cava, the limit must be established around $6 \mathrm{~cm}$ for most cases.

\section{CONCLUSIONS}

Considering our personal experience and data accumulated in international literature since 1992, it can be said that laparoscopic surgery of pheochromocytoma can be safely and efficiently performed in adrenal tumors of small volume, with advantages over open surgery. Laparoscopy can also be indicated in selected cases of bilateral tumors, larger tumors $(>6 \mathrm{~cm}$ in the longer diameter), paragangliomas, and tumors in pregnancy. Partial adrenalectomy should be considered in cases of single gland tumors and in patients who have a good chance to develop bilateral disease, as familiar pheochromocytoma and other genetic disorders.
CASTILHO L N e col. - Feocromocitoma tratado por cirurgia laparoscópica. Rev. Hosp. Clín. Fac. Med. S. Paulo 55 (3): 93-100, 2000.

Objetivo: Avaliar os resultados da utilização da técnica laparoscópica no tratamento do feocromocitoma de supra-renal.

Método: Dez pacientes, sete homens e três mulheres, entre 10 e 67 anos de idade (média 48), com feocromocitoma, foram operados por via laparoscópica transperitoneal e avaliados retrospectivamente, com base nos diagnósticos clínico-laboratorial e anátomo-patológico. Em todos os casos havia um tumor sólido unilateral de supra-renal, cinco à direita e cinco à esquerda, cujo maior eixo variou de 7 a $80 \mathrm{~mm}$ (média 32). Nove dos dez pacientes eram hipertensos crônicos ou tinham história de picos hipertensivos. Um paciente era normotenso, mas apresentava alterações metabólicas sugestivas de hiperfunção adrenérgica.
Resultados: Nenhum óbito ocorreu na série. Houve duas (20\%) conversões para cirurgia aberta, uma por sangramento venoso e uma por dificuldade de dissecção junto à veia cava, cujo paciente apresentava um tumor parcialmente retrocaval. O tempo operatório nos oito casos não-convertidos foi de $70 \mathrm{a}$ 215 minutos (média 136). Um paciente $(10 \%)$ recebeu transfusão de sangue e outro (10\%) apresentou duas complicações - insuficiência renal aguda e infecção de tecido celular subcutâneo. 
Ambos foram convertidos para cirurgia aberta. Nenhum dos casos não-convertidos recebeu transfusão ou apresentou complicação. A alta hospitalar foi concedida entre o $2^{\circ}$ e o $11^{\circ} \mathrm{PO}$ (mediana 3). O exame anátomo-patológico das peças cirúrgicas confirmou o feocromocitoma em todos esses dez casos, num deles associado a um tumor cortical produtor de aldosterona.

Conclusões: A supra-renalectomia laparoscópica para casos selecionados de feocromocitoma é factível e apresenta bons resultados.

DESCRITORES: Feocromocitoma. Supra-renal. Supra-renalectomia laparoscópica.

\section{REFERENCES}

1. GAGNER M, LACROIX A \& BOLTE E - Laparoscopic adrenalectomy in Cushing's syndrome and pheochromocytoma. N Engl J Med 1992; 327: 1003-1006.

2. HIGASHIHARA E, TANAKA Y, HORIE $S$ et al. - A case report of laparoscopic adrenalectomy. Jap J Urol 1992; 83:1130-1133.

3. YOSHIDA O, TERACHI T, MATSUDA T et al. - Complications in 369 laparoscopic adrenalectomies: a multi-institutional study in Japan. J Urol 1997; 157 (supp): 282, 1098A.

4. BABA S, ITO K, YANAIHARA $\mathrm{H}$ et al. - Retroperitoneoscopic adrenalectomy by a lumbodorsal approach: clinical experience with solo surgery. World J Urol 1999; 17: 54-58.

5. BENDINELLI C, MATERAZZI G, PUCCINI M et al. - Laparoscopic adrenalectomy: a retrospective comparison with traditional methods. Minerva Chir 1998; 53: 871-875.

6. DUDLEY NE \& HARRISON BJ - Comparison of open posterior versus transperitoneal laparoscopic adrenalectomy. Br J Surg 1999; 86: $656-660$.

7. FILIPPONI S, GUERRIERI M, ARNALDI G et al. - Laparoscopic adrenalectomy: a report on 50 operations. Eur J Endocrionol 1998; 138: $548-553$.

8. GAGNER M, POMP A, HENIFORD BT et al. - Laparoscopic adrenalectomy: lessons learned from 100 consecutive procedures. Ann Surg 1997; 226: 238-246.

9. GASMAN D, DROUPY S, KOUTANI A et al. - Laparoscopic adrenalectomy: the retroperitoneal approach. J Urol 1998; 159: 1816-1820.

10. HERRERA MF, TORRES G, GAMINO R et al. - Laparoscopic adrenalectomy in a Mexican institution. Rev Invest Clin 1998; 50: $399-404$

11. MIYAKE O, YOSHIMURA T, YOSHIOKA T et al. - Laparoscopic adrenalectomy. Comparison of the transperitoneal and retroperitoneal approach. Eur Urol 1998; 33: 303-307.

12. SHEN WT, LIM RC, SIPERSTEIN AE et al. - Laparoscopic vs open adrenalectomy for the treatment of primary hyperaldosteronism. Arch Surg 1999; 134: 628-631.

13. SHICHMAN SJ, HERNDON CD, SOSA RE et al. - Lateral transperitoneal laparoscopic adrenalectomy. World J Urol 1999; 17: 48-53.

14. SMITH CD, WEBER CJ \& AMERSON JR - Laparoscopic adrenalectomy: new gold standard. World J Urol 1999; 23: 389396.

15. YOSHIMURA K, YOSHIOKA T, MIYAKE O et al. - Comparison of clinical outcomes of laparoscopic and conventional open adrenalectomy. J Endourol 1998; 12: 555-559.

16. TERACHI T, MATSUDA T, TERAI A et al. - Transperitoneal laparoscopic adrenalectomy: experience in 100 patients. J Endourol 1997; 11: 361-365.
17. MÖBIUS E, NIES C \& ROTHMUND M - Surgical treatment of pheochromocytomas: laparoscopic or conventional? Surg Endosc 1999; 13: 35-39.

18. SCHELL SR, TALAMINI MA \& UDELSMAN R. - Laparoscopic adrenalectomy for nonmalignant disease: improved safety, morbidity, and cost-effectiveness. Surg Endosc 1999; 13: 30-34.

19. PIATEK S, MANGER T, KUNZ D et al. - Laparoscopic transperitoneal adrenalectomy - technique and personal experiences. Zentralbl Chir 1997; 122: 1103-1107.

20. JANETSCHEK G, FINKENSTEDT G, GASSER R et al. Laparoscopic surgery for pheochromocytoma: adrenalectomy, partial resection, excision of paragangliomas. J Urol 1998; 160: 330-334

21. TAKAMI H, MIYOSHI H, KODAIRA S et al. - Laparoscopic adrenalectomy in asymptomatic pheochromocytoma. Am Surg 1997; 63: 820-822.

22. COL V, DE CANNIÈRE L, COLLARD E et al. - Laparoscopic adrenalectomy for pheochromocytoma: endocrinological and surgical aspects of a new therapeutic approach. Clin Endocrinol (Oxf) 1999; 50: 121-125

23. DEMEURE MJ, CARLSEN B, TRAUL D et al. - Laparoscopic removal of a right adrenal pheochromocytoma in a pregnant woman. J Laparoendosc Adv Surg Tech A 1998; 8: 315-319.

24. CHIGOT JP, MOVSCHIN M, EL BARDISSI M et al. - Comparative study between laparoscopic and conventional adrenalectomy for pheochromocytomas. Ann Chir 1998; 52: 346-349.

25. TERAI A, TERACHI T, INOUE T et al. - Laparoscopic adrenalectomy for bilateral pheochromocytoma: a case report. Int J Urol 1997; 4: 300-303.

26. MANGER T, PIATEK S, KLOSE S et al. - Bilateral laparoscopic transperitoneal adrenalectomy in pheochromocytoma. Langenbecks Arch Chir 1997; 382: 37-42.

27. MICCOLI P, BENDINELLI C, MATERAZZI G et al. - Traditional versus laparoscopic surgery in the treatment of pheochromocytoma: a preliminary study. J Laparoendosc Adv Surg Tech A 1997; 7:167-171.

28. TAKEDA M, GO H, IMAI T et al. - Experience with 17 cases of laparoscopic adrenalectomy: use of ultrasonic aspirator and organ beam coagulator. J Urol 1994; 152:902-905.

29. JORIS JL, HAMOIR EE, HARSTEIN GM et al. - Hemodynamic changes and catecholamine release during laparoscopic adrenalectomy for pheochromocytoma. Anesth Analg 1999; 88: 16-21.

30. FERNÁNDEZ CRUZ L, SÁENZ A, TAURÁ P et al. - Helium and carbon dioxide pneumoperitoneum in patients with pheochromocytoma undergoing laparoscopic adrenalectomy. World J Surg 1998; 22: 1250-1255. 
31.PRETORIUS M, RASMUSSEN GE \& HOLCOMB GW Hemodynamic and catecholamine responses to a laparoscopic adrenalectomy for pheochromocytoma in a pediatric patient. Anesth Analg 1998; 87: 1268-1270.

32. COL V, DE CANNIÈRE L, MESSAOUDI L et al. - Heart failure induced by pheochromocytoma: laparoscopic treatment and intraoperative changes of several new cardiovascular hormones. Horm Res 1999; 51: 50-52.

33. GILL IS \& NOVICK AC - Laparoscopic versus open adrenal surgery. AUA Update Series 1999; 28:258-263.

34. THOMPSON GB, GRANT CS, VAN HEERDEN JA et al. Laparoscopic versus open posterior adrenalectomy: a case-control study of 100 patients. Surgery 1997; 122: 1132-1136.

35. LINOS DA, STYLOPOULOS N, BOUKIS M et al. - Anterior, posterior, or laparoscopic approach for the management of adrenal diseases? Am J Surg 1997; 173: 120-125.
36. WALZ MK, PEITGEN K, HOERMANN R et al. - Posterior retroperitoneoscopy as a new minimally invasive approach for adrenalectomy: results of 30 adrenalectomies in 27 patients. World J Surg 1996; 20: 760-774.

37. GILL IS, ABDELMALAK B, BRAVO EL et al. - Laparoscopic versus open adrenalectomy for pheochromocytoma. J Endourol 1998; 12: S205 (abstract P18-4).

38. WALZ MK, PEITGEN K, SALLER B et al. - Subtotal adrenalectomy by posterior retroperitoneoscopic approach. World J Surg 1998; 22: 621-627.

39. IMAI T, TANAKA Y, KIKUMORI T et al. - Laparoscopic partial adrenalectomy. Surg Endosc 1999; 13: 343-345.

40. LUCON AM, PEREIRA MAA, MENDONÇA BB et al. - Pheochromocytoma: study of 50 cases. J Urol 1997; 157: 1208-1212.

Received for publication on the $06 / 05 / 00$ 